\title{
Participatory processes for public lands: Do provinces practice what they preach?
}

\author{
Lauren F. Miller ${ }^{1}$ and Solange Nadeau ${ }^{2,3}$
}

\begin{abstract}
Here, we analyze the current spaces for public participation in Crown (public) land management through a comparative study that focuses on the Canadian provinces of New Brunswick and Nova Scotia. We define spaces for public participation as opportunities for meaningful public involvement in the decision-making arena of forest management. We examine the experiences of public participation in these provinces in an exploratory study comparing perceptions of participatory processes and outcomes of the processes in these two provinces based on 15 years (1999-2014) of informant experience. The objective is to understand more fully the barriers and bridges to meaningful public participation and relate these perceptions to on-the-ground implementation. A primary goal is to understand how, over time, processes with unsatisfying outcomes shape the perceptions of the participants. Rather than focusing on one particular participatory process, this comparative study assesses participation over time to identify the limitations in the participatory environments of these two provinces. We take a qualitative research approach using semistructured interviews with 42 forestry stakeholders, combined with participant observation and document analysis. This research reveals: (1) the importance of historical and cultural context as ongoing power imbalances shape the current dialogue and spaces for participation; (2) periods of robust and sound attempts at public participation in both provinces, with disappointments in implementation giving rise to a sense of futility, a closed system, and mistrust of government and industry over time; (3) a system of privileged access in opposition to the ideals of deliberative democracy and an equitable decision-making process; (4) in New Brunswick, public land policy implementation that is not reflective of participatory processes or of interests outside government and industry; (5) in Nova Scotia, recent efforts to incorporate values outside the government-industry policy realm, demonstrating an attempt to shift toward a more collaborative system for public land management.
\end{abstract}

Key Words: agency-client relations; capture; Crown land; forest certification; governance; New Brunswick; Nova Scotia; public land; public participation; sustainable forest management

\section{INTRODUCTION}

Natural resource decision making is hardly ever clear-cut due to the dynamic, multifaceted interdependence of social-ecological and economic systems. Decision making on public land can be especially challenging because policy makers are tasked with balancing diverse societal values with environmental and economic goals in the best interest of the public. To address this complexity, transparency and the inclusion of diverse values and knowledge in the decision-making arena are essential. Sustainable forestry has emerged as an approach to forest management that aims to integrate social goals with the ecological and economic needs of present and future generations. According to the United Nations Forum on Forests, "the sustainable management of all types of forests is vital to facilitate transformative change and address major challenges, such as poverty eradication, economic growth and sustainable livelihoods, food security and nutrition, gender equality, cultural and spiritual values, health, water, energy production, climate change mitigation and adaptation, combating desertification, the reduction of dust and sand storms, biodiversity conservation, sustainable soil and land management, watershed protection and disaster risk reduction" (United Nations 2015:5).

The pursuit of sustainable forest management imparts an expectation of change in the relations with stakeholders. Some level of public participation is needed to gauge public values for achieving the social goals of sustainable forestry. Although traditional natural resource management has often relied on topdown, technocratic decision making (Weimer and Vining 1999), public participation in natural resource decision making is on the rise worldwide.

The Canadian government and the provinces of Canada committed to the paradigm of sustainable forest management (SFM) for public land in the mid-1990s (CCFM 2003). The 2006 status report of the Canadian Council of Forest Ministers (CCFM 2006:177) states,
Forest practices should reflect social values in order to be effective as a mean of moving towards sustainability. This is why Canada's jurisdictions encourage public involvement in their forest management decision-making processes to incorporate the full range of social value and ensure a quicker response to changes in these values over time. Those involved in those processes have commented that they are fair and worthwhile, despite the complex and demanding nature of the exercise. Developing policies and practices that meet the social values of Canadians will not support the goals of sustainability if compliance to the forest management standards defined through these policies and practices is low. Canadian jurisdictions carry out regular compliance assessments and the rate of compliance has generally been found to be high, demonstrating that standards are being successfully enforced.

However, there is no compliance information provided for the provinces of New Brunswick (NB) and Nova Scotia (NS). Because $90 \%$ of Canadian forests are publicly owned and 
managed by the territories and provinces, the forest management approaches and results for meeting sustainable forestry goals vary by province. NB and NS have pursued different policy solutions regarding the sustainable management of forests. Each has its own mandate to manage public land, but for both provinces, the incorporation of public values through public participation remains a challenge. National indicators do not adequately represent these two provinces.

Our exploratory study assesses the challenges to the social goal of sustainable forestry, with particular attention to the avenues for public involvement for different policy-organizational environments within a single federal framework. Much of the research on public participation has focused on case studies that have assessed a variety of concepts related to public participation, including roles of stakeholders, incorporation of public values in decision making, conflict resolution, satisfaction levels of interest groups, perceptions of the collaborative experience, and trust (Anderson and Yaffee 1998, Carr et al. 1998, Beierle and Konisky 2000, Germain et al. 2001, Stringer et al. 2006, Höppner 2009). Additional case study research has assessed the utility of specific participatory techniques (Chess and Purcell 1999, Parkins and Davidson 2008). Other research has attempted to aggregate case study research to create a typology for participatory processes (Chess and Purcell 1999, Rowe and Frewer 2004, Beckley et al. 2006). Here, we provide a unique perspective by assessing numerous participatory processes in two distinct participatory environments as they evolve through time over a period of 15 years (1999-2014). We use this approach to address how processes with unsatisfying outcomes shape the perceptions of participants over time toward the policy and decision-making realm of Crown forest management.

Canada has the third largest forest area in the world and a commitment to sustainable forestry and thus provides a foundation for a comparative study of participatory processes over time through the lens of the provinces. With consideration of the government culture that has shaped forest policy in NB and NS since the start of the industrial era, we examine the outcomes of 15 years of attempts at public involvement. Furthermore, through analysis of key stakeholder perceptions, we have attempted to identify the barriers and bridges that impede or facilitate nontraditional stakeholder involvement in the policy and decision-making realm of forest management on public land.

\section{HISTORICAL-CULTURAL FORESTRY CONTEXT}

Whether the topic is budworms, wood allocation, conservation forest, land tenure, or othewise, "New Brunswick always seems to have a forestry problem that is the basis of local debate" (Baskerville 1995:37). From the time of the earliest inhabitants to the present era, the people of NB and NS have had close ties with the forest and have used forest resources to meet various needs. Although the values and uses of Crown forest differ among stakeholders (e.g., spiritual, aesthetic, ecological functions, recreational, timber harvest, etc.), the primary influence on Crown forest has been the economic engine of the pulp and paper mills. "The pulp and paper mills hold incredible power in communities such as Atholville, Bathurst, Dalhousie, Edmundston, and Newcastle in NB and Abercrombie, Liverpool, and Port Hawkersbury in NS" (Sandberg 1992:11).
Although many citizens feel solid connections to their forests, public participation in public governance has had mixed outcomes. A sound, institutionalized, and consistent process has yet to be established in either province. Public involvement in natural resource management has been on the rise in the $21 \mathrm{st}$ century. According to Baskerville (1988:316), "the current trend in Canada is toward direct public participation in the technical aspects of management design." Despite the national commitment to sustainable forestry (CCFM 2003, 2006), NB and NS have been slow to incorporate public values in the management of forest resources.

Our research focuses on the experiences of key forest stakeholders who have attempted to introduce more inclusive processes of Crown land governance over a 15-year period (1999-2014). Forests are important for all citizens of both provinces; however, we focus on those participatory processes that are not specifically designed to address the Crown's obligation to consult First Nations. In NB and NS, First Nations' rights over the land were established in formal treaties with the British Crown in the early 18th century, and the Supreme Court of Canada has supported timber rights for First Nations in two cases (Wyatt et al. 2015). Regarding general public involvement, numerous published reports have called for more robust, inclusive, and institutionalized public participatory processes (NBDNR 2004, 2005a,b, Select Committee on Wood Supply 2004, Nadeau et al. 2007, NSDNR 2011, 2013b). Both provinces have attempted episodic and mostly reactive participatory processes, with varying degrees of success (see Beckley 2014).

\section{New Brunswick}

The province of NB has an area of approximately $73,000 \mathrm{~km}^{2}$. Forest coverage is estimated at approximately $84 \%$, with $51 \%$ of that representing Crown land managed by the provincial government's Department of Natural Resources (NBDNR) "in the best interest of its citizens" (NBDNR 2004). The legal foundation of Crown forest management is the Crown Lands and Forests Act of 1982. While Crown land covers about half of the province, small private owners control $29 \%$ of forest, with an estimated 41,900 woodlot owners (Floyd et al. 2012), industrial freeholds account for $18 \%$, and $2 \%$ is owned and managed by the federal government (Martin 2003).

In the early years of colonization, NB sought foreign investment in resource extraction to increase jobs, provincial revenue, and electoral support. However, because of the boom-and-bust nature of resource development, by the 1920s, there was a decline in the demand for lumber (Sandberg 1992). Throughout the early 20th century, licenses were granted to harvest lumber on Crown land without any requirement for accountability. A few rules and regulations were in place, but requirements and enforcement were minimal. By 1915, the first pulp and paper mill was erected following the consolidation of numerous sawmills and widespread Crown forestland being allocated to fewer licensees. The transition from sawmill to pulp and paper was accelerated by the lumber market depression in the 1920s. As the sawmills struggled, the government began aggressively pursuing Crown land leases with pulp and paper companies (Parenteau 2013). Pulp and paper emerged as the dominant industrial player, with soaring postWorld War II demand (Martin 2003). By 1992, six large 
transnational corporations controlled the forest industry in NB. Today, there are four companies holding Crown licenses under a license system (Crown Lands and Forests Act) created in 1982 (Martin 2003).

The Crown Lands and Forests Act divides public land into 10 "evergreen" licenses of 25-year duration. With governmental oversight, forest management is assigned to companies with timber-processing facilities (Wallace 2012). The provincial Minister of Natural Resources reviews forest management agreements every five years, and if performance is satisfactory, the license continues for another 25 years (Martin 2003). Forest standards are set by NBDNR, and management plans are prepared by the companies (Wyatt 2014). In 2002 and 2003, the NB government added a requirement for Environmental Management and SFM certifications, with SFM to be determined by the companies. Both of these systems are third-party certification systems and are typically voluntary (Holloway et al. 2008). SFM has the option to add an institutional form of public participation, which is otherwise lacking in NB, with the selection of Canadian Standards Association or Forest Stewardship Council (FSC) certification, which requires stakeholder advisory boards. However, all Crown licensees maintain Sustainable Forest Initiative (SFI) licenses, which do not maintain a public participation component beyond the dissemination of educational material (Ozinga and Krul 2004). The province also issues sublicenses to other commercial timber users, mostly sawmills.

The forest industry in NB has declined substantially over the 21 st century. Since 2000 , approximately $50 \%$ of industrial jobs have been lost (Wallace 2012). The total value of shipments of forest products has spiraled downward from \$4.1 billion CAD in 2004 to $\$ 2.3$ billion in 2009 . However, throughout the recent market crash (2004-2008), the amount of wood cut from Crown land remained moderately steady. The woodlot owners' market for selling wood has taken the largest hit in the total volume sold through the province's marketing boards (Parenteau 2013), with a decline of $60 \%$ ( 1.1 million cords to 400,000 cords). Investment in the restoration of the forest industry and the creation of jobs remains a primary goal of the government.

The most recent forest policy promulgated in 2014 by the Alward government has caused extensive debate because it undermines the previous Alward government's 2012 forest plan. In 2012, Minister Bruce Northrup (under the Alward government) presented a forest plan that maintained 28\% Crown forest as conservation forest. Conservation forest includes protected areas, habitat management zones, and riparian and wetland buffer zones, with timber extraction possible in habitat and buffer zones if nontimber objectives can still be met (Task Force on Forest Diversity and Wood Supply 2008). This plan was a culmination of eight years of debate following a comprehensive study by a consulting company (Jaakko Pöyry), public consultations, and the input of numerous task forces (Task Force on Forest Diversity and Wood Supply in 2008, Private Land Task Force in 2011, Crown Land Task Force in 2011). Although the 2012 plan received mixed responses at the time, with the appearance of the 2014 strategy, many of those involved retrospectively expressed satisfaction with the 2012 policy direction.
The 2014 forestry strategy was released by the same Conservative government without additional public consultation or dissemination of information about the process. The cabinet was rearranged, and Minister Bill Levesque from economic development replaced Minister Bruce Northrup in overseeing natural resources in 2013 (Beckley 2014). The 2014 forest strategy, Putting our Resources to Work: A Strategy For Crown Lands Forest Management, led to contracts between the government and industry guaranteeing additional harvesting of approximately $20 \%$ softwood for 25 years. Much of the policy was a complete reversal of the 2012 forest strategy and reduced the conservation forest to 23\% (Beckley 2014). According to Anderson and MacLean (2015), this policy resulted from the analysis of a narrow range of policy alternatives, ignoring recommendations by the conservation coalition that focused on adaptive management and public participation. Because one of the main focuses of the new policy is job creation, former Premier Alward ${ }^{[1]}$ stated, "It's about putting more boots in the woods and the mills," (CBC News 2014).

\section{Nova Scotia}

Crown land in NS is "all or any part of the land under the administration and control of the Minister of Natural Resources" (NSDNR 2013b). The two Acts governing the harvest of Crown land are the Crown Lands Act (1989) and the Scott Maritimes Pulp Limited Agreement Act (1965). Crown land is currently estimated at approximately $15,400 \mathrm{~km}^{2}$, which is $29 \%$ of the provincial land base. Nearly $70 \%$ of the remaining land base is held in private hands, a distinction from most other provinces. Of the total area of NS, approximately $77 \%$ is forested $\left(42,750 \mathrm{~km}^{2}\right)$, and $68 \%$ of the forestland is privately owned, with approximately 30,000 woodlot owners (Sandberg and Clancy 1996).

NS never became as reliant on one staple as did NB (Burrill and McKay 1987). NS depended on the exploitation of natural resources other than wood, such as coal. However, by the late 1800 s, the province had set up the "Big Lease" (1899) on Cape Bretton Island, the only contiguous, extensive piece of Crown land left. The lease included a generous offer to a large foreign pulp and paper company in which there were two pulp mills built with an annual set fee and no stumpage rate (fee paid to government for the amount of wood cut on public land) collected for $2590 \mathrm{~km}^{2}$ of forest under lease for 33 years, which was later extended to 99 years (Sandberg, 1992). This began an era of corporate consolidation of forested lands in NS (Sandberg and Clancy 1996).

By the mid-20th century, the government of NS was actively recruiting foreign capital investment in new pulp and paper businesses. Agreements were reached with a few companies, some of which were secured and enacted through legislative acts: the Stora Forest Industries Limited Agreement Act (1959) and the Scott Maritimes Limited Agreement Act (1965). The terms for both of these companies were favorable, long term, and focused on the most economical manner to harvest the forest. The Stora Act was originally set up as a 50 -year agreement on $40 \%$ of the province's Crown land, or $11 \%$ of the province. This Act was repealed in 2012 during a time of bankruptcy for the mill company, economic struggles in the forest industry at large, advocacy to repeal this Act, a transition to a new natural resource strategy (2011), and an attempted cultural transition program in 
the NS Department of Natural Resources (NSDNR; NS10 [these numbers refer to stakeholder interviewees]). The Scott Maritimes Act remains in place. NS has moved forward on a single community forest pilot project and, on some Crown land, has transitioned toward implementation of Forest Utilization License Agreements, a new form of renewable licensing. Unlike NB, NS does not have a uniform Crown license system. There is also no requirement for third-party certification on Crown land; however, a recent Minister of Natural Resources has committed to and then retreated from a FSC requirement (Ecology Action Centre: https://ecologyaction.ca/fscstepbackwards).

The most recent strategy for Crown land governance is contained in The Path We Share: a Natural Resource Strategy for Nova Scotia 2011-2020 (NSDNR 2011). In a 24-month progress report published in August 2013, the province admits that it has achieved few of the 32 action items outlined in The Path We Share. Following the 2013 update, NSDNR recognized the slow progress toward actualization of the plan but reemphasized the unofficial motto of "the status quo is not an option" and its commitment to transformative change (NSDNR 2013b:6). The extent of transformative change has been under scrutiny because of disappointment in the latest public involvement process, the Western Crown Land Planning Process in 2013-2014 (Lindsey 2014) and the reduction of the community forest pilot projects to one project of a smaller size than expected (Scrine 2014). Sandberg and Clancy (1996:42) conclude, "the property rights held or conferred on the pulp and paper companies, and the associated powers and privileges that go along with them, have clearly been promoted at the expense of small woodlot owners, sawmillers, subsistence and recreational users of the forest resource." The extent of transformative change to a more inclusive approach to public land management remains uncertain.

\section{BACKGROUND: PUBLIC PARTICIPATION}

\section{Why meaningful public involvement?}

There is neither an overarching public participation theory nor a panacea of participatory techniques to ensure meaningful public involvement. There is a patchwork of theories and approaches and a full toolbox of techniques that guide research and practice (Beckley et al. 2006). Theories of deliberative democracy tend to focus on normative arguments of the importance of participation and the value of public deliberation. Deliberative democracy also examines forms of exclusion and the role that distrust can play in the promotion of participation (Parkins and Mitchell 2005). With a meaningful participatory process in which participants perceive value, the benefits derived include (but are not limited to): (1) increased collaborative learning, (2) enhanced trust and improvements in communication, and (3) augmented relationships (Anderson and Yaffee 1998). Citizen satisfaction also is enhanced when a participatory process is deemed to be fair. Fairness can be judged by the presence of representation and autonomy throughout the process (Hourdequin et al. 2012). Where theories of deliberative democracy have emphasized process, much of the natural resource research has focused on outcomes of participatory processes based on the notion that public participation will lead to improved outcomes. Many public participation studies have focused on particular techniques or compared various processes in different contexts (Chess and Purcell 1999, Rowe and Frewer 2004, Parkins and Davidson 2008) and have added to our understanding of what characteristics lead to more successful processes. Few studies have assessed participatory environments through time. Assessing the participatory landscape over time pinpoints challenges to sound public participatory processes, implementation of these processes, and effects on trust over time.

NB and NS have experienced some success with specific processes to identify and institutionalize protected natural areas (NB's Protected Natural Areas Planning Process, 1998-2003, and NS's Colin Stewart Forest Forum, 2005-2009). Why were these steps more meaningful than other processes? Can we relate the perceptions of success with these processes to outcomes that followed these processes? How do processes with unsatisfying outcomes shape the perceptions of the participants toward the decision-making realm in Crown land governance? What can these outcomes show about the participatory environment?

\section{Connecting public involvement, power, and trust}

With a global trend of decentralization in natural resource management, a more democratized approach to management, signaled by more public involvement, is possible. However, for this transition from centralized decision making to increased local public decision making to lead to more efficient and equitable forms of management and development, institutional changes are necessary. Ribot (2003) discusses the importance of downward accountability and representative authorities with discretionary powers. Here, we focus on stakeholder perceptions of the public participatory processes and outcomes, with the perceptions largely based on the implementation. Downward accountability and representative authorities with discretionary powers are linked to implementation of participatory process policy output because "accountable and equitable processes depend strongly on which local actors are being entrusted with discretionary powers over the natural resource" (Ribot 2003:54). Without discretionary powers entrusted to those involved in a participatory process, implementation is less likely.

Reed (2008) calls for research to evaluate perceptions of outcomes from participatory processes, i.e., gauge whether the outcomes are viewed as being holistic and representative of diverse interests and enhance public trust in the decision-making process. Trust has become increasingly relevant in recent studies, especially for collaborative efforts in governance and management. Trust is the reliance of one group on another under a state of perceived risk (Bachmann and Zaheer 2006). According to Ostrom (2009), empirical studies indicate that trust has a central role in overcoming social dilemmas, and a favorable outcome relies on the likelihood that appropriators will reciprocate in a trustworthy manner. As Schlager (2004:149) states, "increasing dissatisfaction has emerged with the state-centered policy programs pursued. In many instances in which national governments and centralized bureaucratic agencies intervened, claimed ownership ... or imposed regime, results have been disappointing ... governmentowned or managed forests are degraded." Ostrom (1990, 2008, 2009) emphasizes the need for a change in governmental relations with the public and in approaches toward community-based management. This sentiment is echoed by a recent report on shale gas in NB that notes, "to move forward will require indigenous people, communities, industries and government to work collaboratively to design solutions that adhere to community 
values and aspirations" (Léger et al. 2016:2). Schlager (2004), like Fiorino (2006), believes that governing institutional rules require flexibility and diverse approaches to inclusivity. Schlager (2004) also states that there should be more investment in the governing capabilities of the appropriator vs. command and control, and stresses the importance of reconnecting citizens and stakeholders with environmental governance.

Some participants of public engagement processes value being involved for benefits such as increased collaborative learning, enhanced trust and improvements in communication, and augmented relationships. However, over time, unsatisfying outcomes, frequently stemming from lack of implementation, may erode the perceived value of these processes and affect trust in the overall participatory environment. Simmons' (2007) research on participation and power pays particular attention to the ways in which comments from the public are reflected in the final policy. If the public's comments, concerns, interests, and values are not reflected in the final implementation, the public remains powerless, which feeds a sense of hopelessness. This failure of implementation to reflect the public's expectations may further marginalize the public, as well as maintain the status quo as the most desirable approach from the perspective of those with authority (Cook et al. 2013). There is a distinction between a meaningful, satisfactory process with poor implementation and a meaningless process.

In both process and implementation, power is a core element in public participation (Slocum et al. 1995) and it comes in diverse forms. Cook et al. (2013) discuss the power effects of framing participation and how four competing frames shape participation exercises with government, including representative democracy (voice of the public), professionalization (may exclude more inclusive forms), statutory requirements (governmental agenda at play in shaping the process), and evidence-based decision making (technocratic approaches maintained). Thus, the framing of participation processes contributes to understanding the barriers within those processes. In terms of implementation, Beierle and Cayford (2002) describe the true drivers behind actual implementation as regulatory power, program budgets, and staff. These factors are not within the control of the actual public participation processes. Assessing participatory processes through time in two specific contexts allows us to shed light on the extent to which these drivers can act as obstacles in the participatory landscape.

Beierle and Konisky (2000) find that a sound participatory process can lead to success in a variety of contexts. Beierle and Cayford (2002) recognize that it is not likely that contextual issues are irrelevant, and they recommend further analysis. Here, we stress the importance of context to enable a comparison of the two provinces' participatory processes through time. The historical and cultural contexts of these two Maritime Provinces set the stage for understanding the power imbalances that have persisted through time, the high regard Maritime citizens have for Crown forests (public forests managed by the province), and the public's lack of access to the policy-making process for these public lands. These contexts shape the historical attempts at public participation because links between power and public participation shape the outcomes of decision-making processes (Brownill and Carpenter 2007) and are instrumental in explaining the barriers and bridges to meaningful public involvement in public land governance. The context within each province illuminates particular challenges that currently impede a sound and fair institutionalized process. The NB Crown land context has been the focus of numerous historical studies, which have demonstrated the immense power that forest industries have over the direction of public land policy (Sandberg 1992, Parenteau 2013, Anderson and MacLean 2015). Crown forest policy in NB and NS has been compared in other relevant studies that have focused on the case of spruce budworm in NB and NS (Miller 1993, Miller and Rusnock 1993, Sandberg and Clancy 2002). These cases have discussed a culture of exclusion in the Crown land policy-making realm that persists in both provinces to varying degrees.

Deliberative democratic theory is founded on equal opportunity to partake in political life, including government agency decisions (Hourdequin et al. 2012) about public land. Although worldwide there has been a movement toward decentralization of natural resource management (Ribot 2003), the view that experts should manage and educate the public who are seen as ill-equipped to contribute substantively to the formulation of policy persists in many sectors (Simmons 2007). According to Selznick (1949:10), "the difference between officials and ordinary members is the former have special access to power over the machinery of the organization, those outside the bureaucratic ranks lack access to power." This exclusion from democratic participation also occurs when there exists an unequal distribution of power or privilege afforded to specific groups (Young 1990). The exercise of power determines the ability to partake or not partake in a decisionmaking process (Gaventa 1980). Those individuals or groups receiving privileged access violate democratic ideals. Privileged access can shift the dialogue away from deliberative spaces. Without this space for dialogue, more controversy over natural resource decisions can erupt as parties are forced into extreme stances on issues (Cortner and Moote 1999) and have to resort to alternate means to voice their opinions. This reduces the possibility for Madison's democratic ideal of a harmonious balance of factional concerns (Leach 2006) to prevail. From both conflict resolution and public involvement perspectives, reducing power imbalances is necessary for a sound process. The integrity of the process cannot be upheld when the agency overseeing the management of a public resource allows a single interest group, in the midst of competing interests, to dominate the agency's actions.

\section{METHODS}

In our comparative study of participatory processes, we assess the barriers and bridges to sound, comprehensive engagement. Through an exploratory approach, we examine a subject that has not been significantly researched. The data collected are preliminary data that will guide the direction of future research on this topic (Hesse-Biber and Leavy 2011). This research is exploratory because of the extensive time period and number of participatory processes covered in two particular participatory contexts over time. Additionally, the two contexts include the emergence of, and commitment to, sustainable forestry on a national level, with varying mandates and approaches to meeting these goals on the provincial level. The comparative analysis identifies how the characteristics of two distinct participatory environments (in NB and NS, respectively) over a time frame of 
15 years (1999-2014) affect decision-making processes and levels of public trust in the managing institutions. In the research design, we use a qualitative approach with multiple methodologies, including semistructured interviews, participant observation, and document analysis (Diduck and Sinclair 2002, Giddings 2006). Personal attendance at a public forest rally and stakeholder meetings, and reviews of government documents, media files, environmental nongovernmental organization (NGO) documents, and other publications were used to understand and document the context for our research. However, several key stakeholders were unable or unwilling to participate.

To start the identification of potential participants, a panel of three key actors in the forestry community provided independent lists of important stakeholders in the forestry sectors of NB and NS. The lead researcher attempted to contact each person mentioned on the lists. Although contact information was not available for everyone, the lead researcher used snowball or chain referral sampling (Nueman 2009, Ishak and Bakar 2014) to expand the key forestry stakeholder interview participant pool. The study sample was created through recommendations of others who are known to have experience in the topical areas covered by this research (Biernacki and Waldorf 1981), in this case, involvement in Crown land governance in NB or NS. We targeted diversity among stakeholders rather than focusing on a single interest group. In dealing with smaller provinces such as NB and NS, anonymity was maintained by specifying general categories for grouping participants (e.g., industrial perspective, government, NGO, or woodlot owner or association). Although these groups were not homogeneous, they represented the diversity of participants. Many participants strongly identified with more than one "occupational identifier," because the boundaries are fluid. Consequently, the total number of participants was less than the aggregate of participants identified in each category (Table 1). In reporting results, to maintain anonymity, participants were referenced by their province abbreviation and assigned a number (e.g., NB3 for New Brunswick, third interview).

Table 1. List of interview participants' occupational identifiers.

\begin{tabular}{lcc}
\hline \hline Occupational identifier & $\begin{array}{c}\text { New Brunswick } \\
(24 \text { participants) }\end{array}$ & $\begin{array}{c}\text { Nova Scotia } \\
(18 \text { participants) }\end{array}$ \\
\hline $\begin{array}{l}\text { Private consultant } \\
\text { Industrial perspective (small, }\end{array}$ & 3 & 2 \\
medium, and large industry; & 6 & 4 \\
industrial associations) & & \\
$\begin{array}{l}\text { Government: elected officials } \\
\text { (retired, former, current) }\end{array}$ & 3 & 0 \\
$\begin{array}{l}\text { Government: civil servants (retired, } \\
\text { former, current) }\end{array}$ & 4 & 7 \\
$\begin{array}{l}\text { Nongovernmental organization } \\
\text { Academia }\end{array}$ & 4 & 4 \\
Woodlot (owners, associations) & 4 & 1 \\
\hline $\begin{array}{l}\text { Groups are not homogeneous. Many participants strongly identified with } \\
\text { more than one group. }\end{array}$ &
\end{tabular}

The key forestry stakeholders recruited as interview participants in NB and NS have been directly and indirectly involved in participatory processes over the past 15 years. One of our opening questions addressed participatory processes, asking, "Have you ever formally or informally participated in a policy or planning activity in regard to management of or policy making for Crown lands in NB/NS?" This was followed by a request for a description of their involvement in which processes, their role, the participants' view of the effectiveness of their participation, the process, and the perceived outcome. Through this question, we identified the most discussed participatory processes in each province, and those became the focus of our analysis. Other themes covered in the semistructured interviews included participants' understanding and experiences around Crown license tenure arrangements, opinions regarding Crown land forestry policies, experience with dispute resolution mechanisms, and participants' collaborations with other forestry stakeholders. The bulk of the interviews focused on the informants' experiences with participatory processes. The last question was a request for more names and contact information for relevant people. In total, 24 interviews were conducted in NB and 18 in NS, with 23 interviews over the phone and 19 interviews conducted in person. The duration of each interview ranged from approximately 30 $\min$ to $2.5 \mathrm{~h}$.

Following grounded theory (Tuler and Webler 1999, Charmaz 2006), the lead researcher systematically collected and simultaneously analyzed the interviews. The lead researcher audio-recorded all but one interview due to technical difficulties. For each interview, the lead researcher took detailed notes, transcribed, analyzed, and coded using both pen and pencil and NVivo software. Observational data were derived from personal involvement of both researchers over three years in the Community-University Research Alliance in NB, comprising forestry stakeholders discussing various aspects of forestry. The lead researcher gathered observational data in NS from in-person interviews and attendance at a rally in NS promoting a pilot community forest and other topics involving NS Crown land. Finally, the lead researcher analyzed governmental documents, academic publications, nongovernmental publications, and media coverage.

\section{RESULTS}

\section{Most discussed participatory processes}

New Brunswick participatory processes discussed

Participants from NB focused and elaborated on the following processes (Table 2): Protected Area Planning (1998-2003), the Select Committee on Wood Supply (2003-2004), and forest advisory committees (ongoing). Interview participants discussed processes and outcomes. Although the stakeholders interviewed were diverse, their perspectives on most processes and outcomes varied only slightly.

Nova Scotia Participatory Processes Discussed Interview participants from NS elaborated on the following processes (Table 3): the Colin Stewart Forest Forum (2005-2009), Natural Resource Strategy (2009-2010), Western Crown Land Planning Process (2013-2014), and forest advisory committees (ongoing). Interview participants discussed both the processes and the outcomes. Similar to NB, the stakeholders interviewed were diverse. Nevertheless, their perspectives on most processes and outcomes only varied slightly, with the largest discrepancy found in perceptions of the processes surrounding the Natural Resource Strategy. 
Table 2. Characteristics of the most-discussed participatory processes in New Brunswick.

\begin{tabular}{|c|c|c|c|}
\hline \multirow[b]{2}{*}{ Characteristic } & \multicolumn{3}{|c|}{ Participatory process } \\
\hline & $\begin{array}{l}\text { Protected Natural Areas Planning Process } \\
(1998-2003)\end{array}$ & $\begin{array}{l}\text { Select Committee on Wood Supply (2003- } \\
2004)\end{array}$ & Forest advisory committees \\
\hline Purpose & $\begin{array}{l}\text { Develop a comprehensive Protected Areas } \\
\text { Strategy }\end{array}$ & $\begin{array}{l}\text { Reactive process establishing the Legislative } \\
\text { Assembly Select Committee on Wood } \\
\text { Supply to assess public opinion. This } \\
\text { followed public outcry raised by a leaked } \\
\text { letter from the New Brunswick Forest } \\
\text { Products Association to the Minister of } \\
\text { Natural Resources resulting in the hiring of } \\
\text { and subsequent report by a forest } \\
\text { consulting firm Jaako Pöyry }\end{array}$ & $\begin{array}{l}\text { Voluntary stakeholder committees for } \\
\text { Crown licenses "that are used to inform } \\
\text { the public on how management plan } \\
\text { objectives have been met" (NBDNR } \\
\text { 2007) }\end{array}$ \\
\hline Participants & $\begin{array}{l}\text { Public; Department of Natural Resources } \\
\text { and Environment (DNR); committee } \\
\text { (selected by Minister) comprising mining, } \\
\text { forestry, wildlife, and environmental } \\
\text { interests and technical staff at DNR }\end{array}$ & $\begin{array}{l}\text { Public; experts in forest-related issues; all- } \\
\text { party Committee }\end{array}$ & $\begin{array}{l}\text { Stakeholders; industry conducting } \\
\text { process; occasionally DNR }\end{array}$ \\
\hline Process & $\begin{array}{l}\text { Collected submissions from public; } 20 \\
\text { public meetings; recommendations sent to a } \\
\text { forest advisory committee to evaluate and } \\
\text { propose supplementary recommendations }\end{array}$ & $\begin{array}{l}13 \text { public hearings with }>200 \text { oral } \\
\text { accounts; presentations from experts to the } \\
\text { committee }\end{array}$ & $\begin{array}{l}\sim 6 \text { ongoing forest advisory committees } \\
\text { (Parkins et al. 2006) recommended by } \\
\text { DNR; not mandatory under chosen } \\
\text { sustainable forest management } \\
\text { certifications (Sustainable Forest } \\
\text { Initiative) }\end{array}$ \\
\hline $\begin{array}{l}\text { Output from } \\
\text { process }\end{array}$ & $\begin{array}{l}\text { LaPierre report (LaPierre et al. 1998); } \\
\text { commitments of relevance include: } \\
\text { recommendations for } 10 \text { new Protected } \\
\text { Natural Areas }\end{array}$ & $\begin{array}{l}\text { Select Committee on Wood Supply (2004) } \\
\text { report; recommendations of relevance } \\
\text { include: (1) a strategy for public } \\
\text { participation; (2) a process similar to the } \\
\text { Select Committee to be completed in 10- } \\
\text { year cycles; (3) Provincial Advisory } \\
\text { Committee to the Minister of Natural } \\
\text { Resources }\end{array}$ & N/A \\
\hline $\begin{array}{l}\text { Outcome and } \\
\text { implementation }\end{array}$ & $\begin{array}{l}\text { Protected Natural Areas Act (2003); } 10 \text { new } \\
\text { designated areas }\end{array}$ & $\begin{array}{l}\text { The first two recommendations for } \\
\text { participatory procedures not implemented } \\
\text { as recommended. The third } \\
\text { recommendation was implemented, but the } \\
\text { Advisory Committee had not met for an } \\
\text { extended period following release of the } \\
2012 \text { forest strategy, prior to the release of } \\
\text { the } 2014 \text { strategy }\end{array}$ & N/A \\
\hline
\end{tabular}

The participatory processes revealed a number of important factors that supported or impeded a sound process and the subsequent outcomes. Relevant factors include power imbalances, process vs. outcome, foregone conclusions (i.e., backroom deals), privileged access, reliance on SFM certification for input, and common goal and third-party facilitation. The participatory processes are presented with reference to these elements. Power imbalances refer to processes in which there is not a space in which participants have equal input and there is no third-party facilitation to help balance the power. Process vs. outcome refers to a process that is generally viewed in a positive light yet fails to move beyond the process itself and leads to poor implementation. Foregone conclusions refer to a process in which the results are already determined or will not be affected by broader participation, resulting in a meaningless process. Privileged access is defined as giving certain parties special access to decision making, affecting both process and outcome. Reliance on SFM certification is a situation where the participatory mechanisms exist to obtain or maintain certification or the government is reliant on this mechanism for accountability.
Lastly, maintaining a common goal and third-party facilitation are two variables that have emerged as common elements in two of the more meaningful processes that had satisfactory outcomes, i.e., processes from each province focusing on protected natural areas planning. See Table 4 for an overview of the perceptions of the processes and outcomes of all of the participatory events discussed below.

\section{Power imbalances}

Forest advisory committees (ongoing in New Brunswick)

Power imbalances do not always allow input from diverse parties to be recognized, as shown with the forest advisory committees in NB. Opinions expressed about the operation of forest advisory committees convened by licensees were mixed, with several participants noting a positive process, but the majority of participants' comments voicing a negative reaction. The benefits derived from these forest advisory committees include airing grievances, engaging with diverse groups, and dissipating discontent. "As you engage people and people start talking with employees, snowmobile clubs, bird watchers, DNR, and all sorts 
Table 3. Characteristics of the most-discussed participatory processes in Nova Scotia.

\begin{tabular}{|c|c|c|c|c|}
\hline \multirow[b]{2}{*}{ Characteristic } & \multicolumn{4}{|c|}{ Participatory process } \\
\hline & $\begin{array}{l}\text { Colin Stewart Forest Forum } \\
(2005-2009)\end{array}$ & $\begin{array}{l}\text { Natural Resource Strategy } \\
(2009-2010)\end{array}$ & $\begin{array}{l}\text { Western Crown Land Planning } \\
\text { Process (2013-2014) }\end{array}$ & $\begin{array}{l}\text { Forest advisory committees } \\
\text { (ongoing) }\end{array}$ \\
\hline Purpose & $\begin{array}{l}\text { Resolve conflict and work } \\
\text { toward recommendations for } \\
\text { government on how to } \\
\text { complete the protected areas } \\
\text { network for Nova Scotia }\end{array}$ & $\begin{array}{l}\text { Create a new natural resource } \\
\text { strategy guided by citizen input }\end{array}$ & $\begin{array}{l}\text { Decide what to do with newly } \\
\text { acquired public land }\end{array}$ & $\begin{array}{l}\text { Forest Stewardship Council } \\
\text { requirement: "local communities } \\
\text { and community organizations } \\
\text { directly affected by forestry } \\
\text { activities must be given an } \\
\text { opportunity to participate in the } \\
\text { setting of forest management } \\
\text { goals and in forest management } \\
\text { planning" (Maritime Regions } \\
\text { Steering Committee 2008) }\end{array}$ \\
\hline Participants & $\begin{array}{l}\text { Environmental } \\
\text { nongovernmental } \\
\text { organizations; four prominent } \\
\text { forestry companies }\end{array}$ & $\begin{array}{l}\text { Public; key stakeholders; } \\
\text { technical expertise; } \\
\text { Department of Natural } \\
\text { Resources (DNR) }\end{array}$ & Public; DNR & Stakeholders; industry \\
\hline Process & $\begin{array}{l}\text { Collaboration between leading } \\
\text { environmental nongovernment } \\
\text { organizations and four major } \\
\text { forestry companies over five } \\
\text { years; consensus-building } \\
\text { approach with stakeholders }\end{array}$ & $\begin{array}{l}\text { Three phases: citizen } \\
\text { engagement, stakeholder } \\
\text { engagement and technical } \\
\text { expertise, and DNR }\end{array}$ & $\begin{array}{l}\text { Public meetings held with }> \\
700 \text { attendees and } 57 \\
\text { stakeholder groups represented; } \\
\text { online submissions accepted; } \\
\text { three questions asked, and } \\
\text { results and recommendations } \\
\text { put together by DNR }\end{array}$ & $\begin{array}{l}\text { Stakeholder meetings with } \\
\text { companies operating on Crown } \\
\text { land }\end{array}$ \\
\hline $\begin{array}{l}\text { Output from } \\
\text { process }\end{array}$ & $\begin{array}{l}\text { Colin Stewart Forest Forum } \\
\text { final report (Colin Stewart } \\
\text { Forest Forum Steering } \\
\text { Committee 2009); submission } \\
\text { of Protected Natural Areas } \\
\text { recommendations to the } \\
\text { government }\end{array}$ & $\begin{array}{l}\text { The Path We Share: a Natural } \\
\text { Resources Strategy for Nova } \\
\text { Scotia 2011-2020 (NSDNR } \\
\text { 2011); commitments of } \\
\text { relevance include: (1) } \\
\text { commitment to alternatives to } \\
\text { the status quo, including } \\
\text { community forestry; (2) build a } \\
\text { culture of collaboration, } \\
\text { innovation, and mutual } \\
\text { understanding }\end{array}$ & $\begin{array}{l}\text { A Conceptual Plan for Western } \\
\text { Nova Scotia (NSDNR 2013a); } \\
\text { recommendations of relevance } \\
\text { include: (1) general zones for } \\
\text { planning to reflect public input }\end{array}$ & N/A \\
\hline $\begin{array}{l}\text { Outcome and } \\
\text { implementation }\end{array}$ & $\begin{array}{l}\text { Province committed to } \\
\text { reaching } 12 \% \text { protected areas } \\
\text { by } 2015 \text { (reached } 12.26 \% \text { in } \\
\text { December } 2015)\end{array}$ & $\begin{array}{l}\text { Slow implementation } \\
\text { universally (NSDNR 2013b; } \\
\text { one community forest up and } \\
\text { running, and DNR has posted } \\
\text { harvesting sites online with a } \\
\text { window for public comment } \\
\text { (NSDNR 2016) }\end{array}$ & $\begin{array}{l}\text { Latest update August } 2015 \\
\text { without specific planning } \\
\text { details (NSDNR 2015) }\end{array}$ & N/A \\
\hline
\end{tabular}

of interests, what happens is they start exchanging ideas" (NB22; see Fullerton 2012). Essentially, the very existence of these groups provides some space for a specific form of involvement. This level of involvement functions for a few user groups but falls short of expectations for others. Some of the shortfalls experienced include inequitable representation (fairness), attendance issues, concern about a "paper exercise," sentiments of time wasted, and a process involving a one-way flow of information.

Shortcomings may relate to the power surrounding these created spaces, as those who saw benefits from the advisory committees were also representing the industrial perspective and are typically those stakeholders involved in conducting the processes. "There's not a place created for a substantive or broader view of what is happening. It's a controlled response" (NB9). Who creates, populates, and controls the agenda of these committees needs to be considered carefully so that the imbalance of power experienced by participants is addressed. "The idea of having a licensee lead them should probably be looked at or find a different way to do it. I'd be a little afraid that you just wouldn't get the people to come out" (NB14). "It's a joke. The companies that have these public committees give them information they want to give them. These public committees don't get involved in the management side of it. They are simply meeting once a year, and this is the plan, this is what we are going to do, this is what we are going to cut" (NB17). The recommendations in the New Brunswick Crown forest objectives and standards include the suggestion of DNR cochairing with the licensees (NBDNR 2005a). This not only demonstrates a lack of consideration of the power dynamics inherent in the structure of this process, but also disregards the mistrust the public has of industry and government considering that "there is considerable misinformation in circulation and a general mistrust of industry and government by the public" (NBDNR 2004).

Although different perspectives on the advisory process revealed some positive elements and some shortcomings, perceptions of the actual outcomes were similar. Of the responses regarding the 
Table 4. Comparison of selected participatory processes in New Brunswick (NB) and Nova Scotia (NS).

\begin{tabular}{|c|c|c|c|c|}
\hline \multirow[b]{2}{*}{ Participatory process } & \multicolumn{4}{|c|}{ Reaction to participatory process } \\
\hline & Perception of process & Perception of outcome & Facilitator & $\begin{array}{c}\text { Sense of trust } \\
\text { in process }\end{array}$ \\
\hline NB Protected Natural Areas & Majority positive & Majority positive & Yes, third party & Yes \\
\hline NB Select Committee on Wood Supply & Majority positive & Majority negative & Yes, third party & Yes \\
\hline NB forest advisory committees & Majority negative & Majority negative & Yes, usually company & No \\
\hline NS Colin Stewart Forest Forum & Majority positive & Majority positive & Yes, third party & Yes \\
\hline NS Natural Resource Strategy & Majority positive & Majority negative & Yes, third party & Split \\
\hline NS Western Crown Land Planning Process & Majority negative & Majority negative & Yes, government & No \\
\hline NS forest advisory committees & Majority positive & Majority positive & Yes, usually company & Yes \\
\hline
\end{tabular}

outcomes of forest advisory committees, the respondents were all disappointed. "Most of the people on there were good intentioned, but it wasn't going to change anything ... that was a given that it was going to stay the way it was" (NB10). This disappointment in forest advisory persists 11 years after the recommendations by the Legislative Select Committee on Wood Supply (2004:iv) "that as soon as possible, the purpose and function of the License Stakeholder Committees be clarified and enhanced."

Hiring a professional third-party facilitator is rare in the Atlantic region according to the 2006 forest advisory committee survey (Parkins et al. 2006). It is more common that an industry representative facilitates the committees. This demonstrates how the space created for forest advisory committees is a space that reproduces existing power imbalances, which can impede meaningful participation, intensify the sense that the exercise is more procedural than substantive, and build mistrust in the process. According to Gaventa (2006), both the theoretical and physical spaces of a public engagement process are important because the spaces rely on the associated power dynamics, which are not neutral. "Space is a social product ... [a] humanly constructed means of control, and hence of domination, of power" (Lefebvre 1991).

Whereas there is evidence of respect for other participants, as demonstrated above with "good intentioned" people, building trusting relationships with diverse stakeholders is difficult to achieve without an even playing field and power redistribution. Building trust in the participatory process is important. This is not achieved in these forest advisory committees. Given that the pulp and paper industry historically has dominated the policy and management realm of the Crown forest, and in NB there are 50 forest-dependent communities (Wallace 2012), a company-led process may not encourage participation from diverse groups with unique concerns. Many participants have mentioned the useless nature of these groups and the strong opinion that diverse inputs will not be recognized.

\section{Process vs. implementation}

Select Committee on Wood Supply (2003-2004)

One of the prime examples of a good process followed by poor implementation is the Select Committee on Wood Supply in NB. One of the products of the committee was a comprehensive report (Select Committee on Wood Supply 2004). The majority of participants who commented on the process of the Select
Committee on Wood Supply supported it, with only one participant questioning the value of the process. The positive reflections on this process, which occurred 11 years prior, included the valuable discussions, inclusivity of the process, time worthiness of the process, and satisfaction with the well-informed speakers. The comments also discussed the "phenomenal comprehensive report that more or less reflected what the committee heard around the province" (NB3), a "sound report that is as objective as I have seen in regards to some of the issues" (NB8), and that "it was an excellent process and it was a good report" (NB10).

In assessing perspectives on the implementation that followed the Select Committee on Wood Supply, there were no positive comments. A shared sense of disappointment with implementation emerged from these interviews: "[it] was all ignored ... it's just a slap in the face to the user groups. They are all volunteers. They spent all that time and energy" (NB15), "the government didn't actually do anything with the results of that committee and that was not very satisfying" (NB7), and "the implementation has been terrible" (NB6). "One of the recommendations of the Select Committee was that the province establish a defined process for public consultation that should include something like the Select Committee every 5 or 10 years ... the province hasn't done that ... it hasn't developed a policy or meaningful policy on public consultation. It certainly hasn't repeated the Select Committee approach" (NB9).

The recommendations on public involvement and accountability from the Select Committee on Wood Supply included the preparation of a strategy for public participation, an institutionalized process resembling the Select Committee every 10 years, the production of an annual "state of the forest" report, and improving the license advisory process (Select Committee on Wood Supply 2004). Even though implementation of a number of recommendations for public involvement and accountability has not met expectations, the reflections from participants on the process remained positive. The Select Committee process, which was valued and viewed as meaningful, has yet to be repeated. The state of the forest report was issued only once (Auditor General of New Brunswick 2015). There is no evidence of improvements in the license advisory process, which we discuss in the subsection Reliance on sustainable forest management certification, Forest advisory committees (ongoing in Nova Scotia).

Although there has not been another process similar to the Select Committee on Wood Supply, a public opinion poll was 
administered in 2007 funded by NBDNR. The objective was to understand the values the public hold toward the forests and their management and to disseminate this information via presentations throughout the province. With $>1500 \mathrm{NB}$ residents participating in the mail survey, the public was provided with a provisional space to express their opinions and attitudes on Crown forests. The survey provided the government with information on the public's perceptions of Crown lands and their thoughts on how Crown lands should be managed (Nadeau et al. 2007). This poll provided a temporary and anonymous space for a form of public involvement, but it was a one-time action, and the dissemination of information was halted when the government pulled out for unspecified reasons. The cancellation of the nine-city tour to disseminate the information came from the research team's contact in NBDNR within a couple of hours of a cabinet meeting. This was followed by phone calls to the supervisors of two of the research team members discouraging the tour (Beckley 2014). Many New Brunswickers active in the forestry debates point to this survey as the most recent and most accurate reflection of citizen values and preferences because of the scope of the survey, adherence to good social science practice, and ability for citizens to participate anonymously.

Lastly, fulfilling a recommendation of the Select Committee, there was a Task Force on Forest Diversity and Wood Supply created in 2005 that brought together select stakeholders to "develop a set of realistic and practical forest management alternatives that would encompass a broad range of possible ways for managing NB's public (Crown) forest" (Task Force on Forest Diversity and Wood Supply 2008:viii). Although the Task Force brought together various perspectives and alternatives to status quo management, it remained a rather closed, technocratic process for establishing management scenario recommendations for the Minister of Natural Resources. As a technocratic process, the science of timber supply modeling remained the focus and limited the incorporation of diverse social values.

The Select Committee on Wood Supply was initiated in 2003. From 2003 to 2008, there were four different Ministers of Natural Resources. Changing circumstances is one reason Beierle and Konisky (2002) point to a disconnect between public participatory processes and implementation. The problem of exclusion is another. Following the Select Committee on Wood Supply, there has not been a robust, inclusive process, with the exception of the assessment of public perception in 2007 based on a public opinion survey. This participatory landscape has episodically allowed diverse input outside the industry-government realm to shape the vision for managing Crown forests. However, the door has closed on these outside sources at the stage of policy implementation.

Natural Resource Strategy (2009-2010)

A second example of poor implementation is the Natural Resource Strategy in NS. Responses were somewhat divergent on the process leading to the creation of the Strategy. Some of the more positive elements included robust stakeholder involvement and a third-party facilitator (Voluntary Planning) to ensure deliberative space and dialogue, "and not an opportunity for special interests to control or shape the agenda" (NS9). Others felt that the tiered approach of the participatory process was not true participation because the public's input stopped at that first step, creating concerns about fair representation and panel selection:

\begin{abstract}
The strategy development had a lot of positive stakeholder involvement, a lot of solid input. But then you had a situation arise where you had the technical panel that was established to process that input and make recommendations for that strategy, essentially that panel split ... it effected no real change. It's that kind of manipulation of the process that breaks down trust, and people start to feel like, why the [expletive] did I participate in this process when we yielded this great report and you're just going to find every opportunity to undermine it and remain with the status quo? (NS3).
\end{abstract}

With the split of the technical expertise panel on forestry, two distinct reports were submitted to the government. One report, the Bancroft/Crossland report, was a collaboration between Bob Bancroft, a former biologist with NSDNR, and Donna Crossland from Parks Canada. The other panel expert Jonathan Porter, a former Bowater employee and current Director of Forestry at NSDNR, submitted a separate forestry report to the government (NS12). The technical experts from each panel presented their reports to the government to inform the Natural Resource Strategy.

Whereas the process was presented as a meaningful attempt by government to engage the citizenry, some interview participants questioned the intentions of the NSDNR and its ability to surrender control of the process. There is much evidence of stakeholders' lack of trust in the NSDNR in managing public lands. Nonetheless, some interview participants felt that the attempts at a sound participatory process were real; the outcomes fell short of expectations for various reasons (Table 5).

Table 5. Nova Scotia stakeholder comments on natural resource strategy.

\begin{tabular}{|c|c|c|}
\hline \multicolumn{2}{|c|}{ Respondent } & Response \\
\hline NS1 & $\begin{array}{l}\text { "It [B } \\
\text { docur } \\
\text { signif }\end{array}$ & $\begin{array}{l}\text { as a very impressive, excellent } \\
\text { ing dust. I haven't seen any }\end{array}$ \\
\hline NS1 & $\begin{array}{l}\text { "I wa } \\
\text { some } \\
\text { They } \\
\text { and p } \\
\text { this g } \\
\text { imple } \\
\text { whole } \\
\text { comp } \\
\text { did gc } \\
\text { extren } \\
\text { hands }\end{array}$ & $\begin{array}{l}\text { rnment actually came out with } \\
\text { nents, promises to move forward. } \\
\text { ansparency, public engagement, } \\
\text { ecision-making process and all of } \\
\text { uff. None of those was actually } \\
\text { Ultimately, it seems that the } \\
\text { atural Resources Strategy has } \\
\text { ing, the Nova Scotia government } \\
\text { unity forest project... it was an } \\
\text { a bit of land over into the }\end{array}$ \\
\hline NS15 & $\begin{array}{l}\text { "The } \\
\text { take d } \\
\text { Natur } \\
\text { away }\end{array}$ & $\begin{array}{l}\text { its willingness to listen and } \\
\text { zenry, the DNR [Department of } \\
\text { didn't want the control taken } \\
\text {, }\end{array}$ \\
\hline
\end{tabular}

One policy reform was the creation of a single community forest pilot project. However, most respondents were extremely disappointed because the government gave the impression that numerous community forests of larger areas would be piloted (Scrine 2014).

Historically, the opportunity to harvest timber on provincial Crown land was limited to a few large companies. The focus was 
on finding wood to meet needs identified by those companies. Community groups and other interested groups have called on the government to revise the current ways of distributing timber licenses and other rights to provincially owned forest resources. Community working-forests and working-forest conservation and easements offer two options for improving the economic, environmental, and social balance. NSDNR will work with interest groups to develop and test these approaches (NSDNR 2011).

There was some sense of a window opening and real effort put forth to incorporate public values in the Natural Resource Strategy. Participants were especially excited by bringing in Voluntary Planning, which was at an arm's length of the government and was responsible for coordinating public engagement on major issues until it was dismantled in December 2010. Trust in the NSDNR to carry out a sound participatory process is lacking. The presence of a third-party facilitator to ensure objectivity and a more balanced playing field can potentially rebuild trust in the process. However, if implementation is consistently lacking, trust may not be created.

Many participants were disappointed because of a disconnect between what was recommended and what was subsequently delivered. The documents published from each phase and the final Natural Resources Strategy present overarching goals of collaborative leadership, sustainable resource development, research and knowledge sharing, and good governance. Much of the final document The Path We Share: a Natural Resources Strategy for Nova Scotia 2011-2020 shows an understanding of meaningful public involvement and the steps necessary to incorporate values identified by the public during the citizen engagement phase. However, implementation of the goals has not met the timeline presented, and this pace affects how some participants view the participatory environment and develops their sense of mistrust. Although a third-party facilitator guided much of the process, the government ultimately is responsible for timely implementation.

\section{Privileged access and foregone conclusions}

Western Crown Land Planning Process (2013-2014)

Privileged access is closely related to power imbalances, but we combine privileged access and foregone conclusions specifically to describe the process and slow implementation of the Western Crown Land Planning Process in NS. In December 2012, the NS government purchased $2226 \mathrm{~km}^{2}$ of land from Bowater Mersey Ltd. This Crown land acquisition became available because of the closure of the Liverpool mill, which was one of three historical pulp and paper strongholds in the second half of the 20th century. The Bowater acquisition augments already existing Crown land to $6070 \mathrm{~km}^{2}$, which is currently under a new planning process, the Western Crown Land Planning Process (NSDNR 2013a).

Interview respondents were in agreement, albeit with negative views, about the Western Crown Land Planning Process. From those who participated directly or indirectly, there were only negative observations such as “the province hasn't followed its own process in what was proposed in terms of consultation and seeking consultation and input from others and considering alternatives..." (NS6). The process disappointed participants because expectations of participants were not met, there was dissatisfaction with consultation efforts undertaken by NSDNR, the process was perceived as too high level (with very general questions predetermined without public input), and a "backroom" deal for wood allocations was exposed during the public consultation.

It was really high level; it was like these three questions. They had some forest advisory committee and some public sessions and a stakeholder session ... that one was just appearing to be doing consultation and engagement, but it was a zoning exercise. I would say it was an absolute waste of time. And it was really just an exercise in pretending to engage the public ... when it was time to make decisions, it was a table of exclusively DNR staff, and I doubt they even kept minutes. (NS4).

This sentiment was exacerbated by the emergence of a backroom commitment from the province to Northern Pulp to increase its Crown allotment from the western Crown land. The previous government made the commitment, yet the current Minister of Natural Resources, Zach Churchill, says that he plans to honor the commitment, leading many to believe they participated in meaningless consultation after the Northern Pulp deal was done (Lindsey 2014). "I would say that a broad sentiment by the people expressed in the room having various interests, some environmental, some industry, was that the Department had not pursued its consultation process and consideration of alternatives in the way that it has proposed" (NS6).

The sentiment regarding the implementation was also negative. "It's status quo continued" (NS15). Participants expressed continued confusion of what was happening with the western Crown lands. "It is not specific enough and publicly available enough. I still don't know the who's and where's of the western Crown land, and it would be nice to know that" (NS16). For the process and implementation, the participants expressed a feeling of exclusion and closed-door decision making. "I realize a lot of those licenses are area based, and I've been told some of them are volume based. It is confusing when you ask two different people and you get two different answers on licenses. It is one of those things that seems to happen quite a bit behind closed doors" (NS16).

As is evident in many of the responses, participants were disappointed. Expectations on public consultation were not met. This participatory process did not involve "outsiders" to contribute to agenda setting or take part in the early stages. Additionally, the exclusion and maintenance of power within NSDNR are revealed in the third question: "What other points do you feel are the most important for the Department to consider as it develops the land and resource management plan?"(NSDNR 2013a). This question demonstrates an avenue for input, but how will these inputs be considered? Will there be spaces for deliberation for the topics mentioned or does the Department take over from this point onward?

In March 2014, NSDNR released A Conceptual Plan for Western Nova Scotia, which details general designation zones that endeavor to align with public values. However, information regarding specific management and operational plans, as well as the formation of a new consortium with 16 industrial forestry players (personal communication, 2014) remains unclear to the key 
stakeholders interviewed and to the general public. Following the Natural Resource Strategy process, the Western Crown land Planning Process was more rigid, allowed for less genuine participation, and did not meet the expectation for public involvement that the Natural Resource Strategy had proposed. The current participatory mechanism put in place for the western Crown land is public access to interactive maps with management plan details, which accepts input for a designated period prior to action being taken (personal communication, 2014). Much skepticism remains about how input is incorporated in the planning process and how this will effect real change.

\section{Reliance on Sustainable Forest Management certification}

Forest advisory committees (ongoing in Nova Scotia)

SFM certification has different requirements under each type of certification to meet the social side of sustainability. For FSC, one of the requirements is a forest advisory committee. To maintain anonymity, we aggregated information on forest advisory committees into one category. During data gathering, the Medway Community Forest was being launched. Therefore, it is important to note that this analysis excludes the recent forest advisory committee involved with that project.

In contrast with some of the experiences in NB, participants of forest advisory committees in NS had only positive responses when addressing the process of the stakeholder group meetings and many related the successes of the forest advisory committees to the implementation of the FSC certification. "One of the really good things of FSC over other certification systems is it does require public input in the process and, in its Crown land management, the requirement for public input is bigger and more stringent" (NS14). One participant stated, "I think the best, the only opportunities that exist are these forest advisory committees at each mill" (NS4). "Some of the ways in which more diverse group representation is maintained is through the company paying the mileage for people to participate" (NS11). Another reported reason for success is the tradition of this form of engagement and the duration of this committee model: "the previous owners of the mill had the same model where they brought everybody to the table" (NS4).

This model of public engagement through a forest advisory committee has existed for an extended period of time in NS. Although FSC requires forest advisory committees, some committees were created prior to this requirement. In 2015, Minister Churchill committed to FSC certification on western Crown land, and many Nova Scotians viewed this as a move toward a more collaborative approach to natural resource management in accordance with the Natural Resource Strategy. Churchill rescinded that commitment in early 2016 following an audit that raised some concerns about certification in the Medway District, which covers 90,000 ha of the western Crown land (Ecology Action Centre: https://ecologyaction.ca/fscstepbackwards). As a consequence, forest advisory committees remain voluntary. Thus, whereas forest advisory committees are set up by industry without much requirement in terms of governance or processes in NB, NS advisory committees have been largely shaped by the requirements of FSC certification, an external force that can create spaces where it is more difficult for the elite to exert their traditional style of power.

\section{Common goal and third-party facilitation}

\section{Protected Natural Areas Planning Process (1998-2003)}

The majority of forestry stakeholders interviewed were positive and supportive of the Protected Natural Areas Planning Process in 1998-2003 in NB. Although the process commenced with a contentious discussion among numerous interest groups, a deliberative space was created to express opinions, understand divergent viewpoints, and find a path to consensus. Participants commended the diversity in representation (fairness) in both the public hearings component and the advisory committee that followed.
It was very contentious, and a lot of very strongly divergent views were expressed publicly in the media ... all the people were there: scientists who worked in a variety of institutional settings-universities, federal research labs, provincial government departments. The local advisory committee was established, and there were all kinds of folks ... people interested in ATVs, snowmobiling, camp owners, people interested in outdoor recreation, trails, mining... (NB5).

The outcomes from the participants' perspectives were also positive. "They created the legislation and then protected the first round of areas. It was as effective as we could get" (NB7). With the implementation of more comprehensive legislation to manage the protected areas network (Protected Areas Act in 2002), followed by the 10 recommended protected area sites authorized by legislation in 2003, many participants felt the outcome was a success.
I think notable would be the forest advisory committee that worked on the Protected Areas Strategy that ended up being a consensus report of Louis LaPierre. It was presented to government with a paper and conclusions based on his public hearings, and he had a number of recommendations ... I think the outcome and the process that was undertaken was very constructive and it went from rather actively expressed animosity among the membership to people agreeing that they had arrived at a reasonable consensus product, and they also appreciated that that was necessary to allow for constructive development of the required regulation and legislative changes. (NB8).

Direct and indirect participants of this protected areas planning process commended the process and outcome. A few notable characteristics of this process are the third-party facilitation with Louis LaPierre from academia, numerous public meetings with opportunity for public submissions, and the diverse stakeholder groups that were consulted. However, the process did remain science based, with public values only sought following the designation of certain sites rather than having the public involved in earlier stages (Beckley 2014). The Minister also maintained power through committee member selection rather than creating a more open process for this selection. Nonetheless, participants felt it was a fair (good representation), effective process with tangible results. An additional observation is that the process had a vision, or, from a conflict resolution viewpoint, a superordinate goal. This goal, to create a protected areas network, encouraged 
diverse parties, who, while disagreeing on many other aspects of Crown forest management, came together on this overarching goal.

Colin Stewart Forest Forum (2005-2009)

Similar to the Protected Natural Areas Planning Process in NB, which was well received, interview participants applauded the Colin Stewart Forest Forum (protected natural areas process in NS) in terms of the process and implementation. There was only one critique concerning the utility of FSC certification and the narrow focus of the Colin Stewart Forest Forum. "[The Colin Stewart Forest Forum] led the way for FSC to be overwhelmed with Protected Areas and not be about forestry practices. That became a pivotal issue because really it [Port Hawkesbury] was being certified based on Protected Areas, with forestry practices not improving" (NS14).

There was praise for the meaningful and thoughtful public involvement, with numerous opportunities for participation and extensive meetings and consultation. "The Parks and Protected Areas Plan had a lot of consultation over a really long time to help really shape that. They had three rounds of consultation that went into identifying the Protected Areas Network" (NS4). The facilitator helped set up the process, with objectives and expectations for the parties from the start, which provided vision and clarity in the process. "There were some great successes because you were able to draw clear lines [about] what expectations were around the table and what was needed to satisfy those on all sides and develop a concrete path to go forward" (NS13). Additionally, the Forum included diverse stakeholders who were committed to the process throughout and were able to come to a consensus and joint proposal for the government.

\section{From 2004 to 2009, the Collin Stewart Forest Forum expanded its membership beyond the three environmental groups and four companies that originally signed the Memorandum of Agreement. Two governmental departments came to the table, a couple more NGOs came to the table, and over a four-and-a-half-year period, we labored over a proposal to the government on how to finish up the protected areas network. Arguably, that was a key cog in the wheel of getting us to $12 \%$, and now we are past $12 \%$. That should make you drool if you like PNA [protected natural areas] because NB is down to 3 or $4 \%$ or some ridiculously low number. (NS2).}

A third-party facilitator helped lead the process, rather than the government, and numerous informants mentioned this as an important driver of success. Thus, the third-party facilitator, numerous extensive meetings, and consultations set the stage for a successful process, and this was followed by actual implementation from the process stage. The process led to a desirable outcome, with most of the major players in the forestry sector involved in the process, ensuring both fairness through representation and pressure on the government to move forward with the recommendations.

\section{DISCUSSION}

In the late 1980s, Burrill and McKay (1987:95) described the political landscape of forestry issues in the Maritime provinces as "the rival scientific claims of pulp and paper companies, provincial governments, and critical environmentalists are paraded before uncomprehending justices, a predictably proindustry media, and a divided public." After conducting interviews with many key stakeholders involved in the forestry sector, we found that there are similar opinions of what public involvement processes were meaningful and why (from willing participants), rather than the superficial appearance of a severely polarized arena of opinions. Analyzing the participation in various processes to understand the participatory landscape has revealed some of the barriers and bridges to public involvement in Crown land governance, including the effects of agency-client relationships on the participatory environment.

Historical power imbalances continue to shape the current dialogue and spaces for participation. This skewed power dynamic can breed sentiments of hopelessness and futility because of a lack of trust in the institutions that lead these processes. This is especially true when there have been robust and sound attempts at public participation, though typically episodic and reactive, in both provinces that have failed in the implementation phase. What can follow is a sense of meaningless involvement, a closed system, and mistrust in the government and industry. Reed (2008) discusses the need for participatory processes to be institutionalized rather than episodic to facilitate an organizational culture that enables a meaningful process in which goals are negotiated. Early involvement is necessary to avoid the sense of a "forgone conclusion," which is a barrier to public involvement, as seen in Diduck and Sinclair's (2002) research. This occurs when the decisions are determined prior to public involvement, as was the case in the Western Crown Land Planning Process, in which there was a side agreement between the government and Northern Pulp (Lindsey 2014).

\section{Captured policy environment}

The policy environment in which these participatory processes take place is significant. The 2014 New Brunswick Forest Strategy exhibits features of capture with its notable culture of exclusion of diverse clientele and outside interests. Agency capture is the concept that a governing agency is not able to manage on behalf of the public because of close association with and cooptation by a particular interest group (Singleton 2000). Capture in this context denotes the influence exercised by one homogeneous group over a governing agency (Culhane 1981). This notion of capture is typically applied to agencies that are tied to their regulated clientele through the agency's mission. A key characteristic of a captured institutional environment is that the regulatory agency is not likely to seek out new clientele when confronted with active resistance from the existing clientele (Fortmann 1990), breeding a culture of insulation. This culture of insulation is not new to NB, and it persists (Parenteau 2013). Miller (1993) demonstrated, in his study on the role of citizen science in natural resource decision making, that NB has taken a "techno-corporate approach to resource utilization, one that is resistant to the alternative visions of resource use offered by environmental interest groups and, as shown, provides relatively few mechanisms for meaningful public participation in natural resource decision-making" (Miller 1993:57). Miller (1993) concludes with a pessimistic view regarding opportunities for meaningful public participation in this environment without transformative political change.

Implementation of the recommendations from participatory processes in policy making has failed in NB because the space 
Table 6. Comparison of recent forest strategies in New Brunswick and Nova Scotia.

\begin{tabular}{|c|c|c|}
\hline Characteristic & New Brunswick & Nova Scotia \\
\hline Report title & $\begin{array}{l}\text { A strategy for Crown lands forest management: putting our } \\
\text { resources to work (NBDNR 2014) }\end{array}$ & $\begin{array}{l}\text { The path we share: a natural resources strategy for Nova Scotia } \\
2011-2020 \text { (NSDNR 2011) }\end{array}$ \\
\hline Summary & $\begin{array}{l}\text { "This strategy is intended to take advantage of the renewable } \\
\text { resource New Brunswickers own by encouraging investment, } \\
\text { putting hundreds of additional people to work in a vital } \\
\text { industry, and sustainably managing our Crown forests." }\end{array}$ & $\begin{array}{l}\text { "Traditional practices in many resource-based industries are } \\
\text { not sustainable. Markets have changed. The future of our } \\
\text { resource sectors, and of our natural resources themselves, } \\
\text { demand that we change too." }\end{array}$ \\
\hline Strategy development & Unclear & $\begin{array}{l}\text { "The natural resources strategy was developed in consultation } \\
\text { with thousands of Nova Scotians. Phase 1- Citizen } \\
\text { engagement; Phase 2- Stakeholder engagement/Technical } \\
\text { expertise; Phase 3- Government's response: a 10-year plan for } \\
\text { collaborative stewardship." }\end{array}$ \\
\hline Strategy vision & $\begin{array}{l}\text { "Encouraging investment: This strategy will make more } \\
\text { Crown wood available to industry." } \\
\text { "Our vision is for the long term. With this in mind, our } \\
\text { Government is increasing the sustainable harvest of softwood } \\
\text { by } 600,000 \text { cubic meters to match our overall timber objective } \\
\text { of approximately } 3.9 \text { million cubic metres. Furthermore, we've } \\
\text { identified a timber objective for hardwood species at } 1.8 \\
\text { million cubic metres." }\end{array}$ & $\begin{array}{l}\text { "The strategy is grounded on the values of sustainability, } \\
\text { diversity, collaboration, transparency, and informed decision } \\
\text { making, values expressed by Nova Scotians in Phase 1." } \\
\text { "Forests provide more than timber and jobs ... balancing } \\
\text { social and economic costs and benefits, while not always easy, } \\
\text { will ensure our forests are both economically and } \\
\text { environmentally sustainable. This requires improvements in } \\
\text { our forest management practices, to build an ecologically wise } \\
\text { culture for the } 21 \text { st century." }\end{array}$ \\
\hline Strategy goal & $\begin{array}{l}\text { "A key goal of this strategy, then, is to put New Brunswick } \\
\text { forestry sector in a stronger position to thrive and compete- a } \\
\text { sector that is able to sustain itself through the down periods in } \\
\text { this historically cyclical industry." }\end{array}$ & $\begin{array}{l}\text { "It has become apparent through innovative three-phase } \\
\text { development of this strategy that our economic, } \\
\text { environmental, and societal values are out of balance. With } \\
\text { this strategy, we have set goals to restore that balance; to } \\
\text { ensure our province is a place where a diverse mix of life- } \\
\text { biodiversity thrives and contributes to economic growth for } \\
\text { our children and their children." }\end{array}$ \\
\hline
\end{tabular}

does not exist for diverse interests, and the government does not seem inclined to favor public over private interests when there is occasional, clear evidence of a discrepancy between public preferences for Crown land management and the interests of private industry users of that land. Policy has clearly followed historical trends of accommodating industrial interests (Parenteau 2013), revealing a captured environment and a participatory landscape in which implementation of values outside of the historical status quo has been seriously lacking. Economic viability of the pulp industry remains the dominant driver, in contrast to other values that have surfaced in episodic public participatory processes. In NS, the progressive dialogue emerging in the public arena has been reflected in that province's most recent natural resource strategy. This strategy discusses the inclusion of public values with scientifically sound methods to manage Crown land forest. Because of slow implementation and disappointment in the latest participatory process (Western Crown Land Planning Process), the government is under scrutiny for not following its own policy and for reaching a deal with the paper industry without much public input. Table 6 highlights and contrasts key points from each province's published strategy on sustainable forest management.

\section{Reflection on participatory processes}

The more successful participatory processes (those valued or viewed in a positive manner) almost uniformly had a third-party facilitator. When there is distrust of an institution or individual, having a process facilitated by a third party adds to a perception of meaningfulness and value in the process. Other important elements are diversity of the participants and opportunities to participate; these elements were missing in the most recent NB strategy, but were included in the NS strategy. Outcomes in NS demonstrate an understanding of the importance of public opinion and values in creating a new vision for Crown forest governance, at least on paper.

An interesting finding is the disconnect between process and implementation. The on-the-ground participatory landscape parallels the disconnect in the research literature, with the separation of deliberative democracy literature (process) and natural resource management literature (implementation). If a process is perceived to be meaningless, a negative outcome follows. However, if there is a positive process, with a negative outcome, participants are disappointed because their expectations are not met. Nevertheless, many participants will still commend the process. The outcome does not necessarily affect how participants value the process, if the process is meaningful. An exception to this is the Nova Scotia Natural Resource Strategy. However, the perceptions of the process were mixed, rather than completely positive, and perceptions of the outcomes were negative. The context remains relevant because many participants pointed to specific process problems that were not directly related to implementation. With repeated disappointment in implementation, participants' perception of and trust in the institutions involved may deteriorate. As many informants noted, numerous participatory processes felt like procedural exercises, followed by a lack of, or inadequate, implementation. Understanding this context may lead to a more critical evaluation of future processes, as well as better process design and implementation.

Other limitations observed include governmental reliance on SFM certification schemes. While forest certification 
organizations, through their respective forest certification frameworks, create spaces for public participation, it is not desirable that those mechanisms become the sole institutionalized, active avenue for public input. From a public perspective, this means that opportunities for input are defined by a third party over which they have very limited control. Our results show that while the impact of FSC forest certification was perceived rather positively in NS, the impact of SFI certification in NB, where all public forests are SFI-certified (CCFM 2016), went unnoticed among study participants and did not measurably affect participatory processes. Until 2015 , this system only encouraged a one-way dissemination of information, which may exacerbate the inherent power imbalance, issues with privileged access, and institutional mistrust. The auditor general of NB in her 2015 report (Auditor General of New Brunswick 2015) notes,

In its role as the steward of a critically important public asset, our Crown forest, I believe government must protect the interests of New Brunswick residents ... In our two audits, we observed that economic development has become the primary focus of government in relation to the Crown forest. This focus on economic development will likely impact on the long-term bio-diversity of the Crown forest (i.e., softwood species are in higher demand, most marketable, and therefore the focus of provincial silviculture activities). It may also have the effect of excluding other prospective commercial and non-commercial users of the Crown forest.

The exclusion of diverse clientele and interests and the promotion of the historically dominant industrial approach is indicative of a captured environment in NB. In NS, the government is committed to moving away from the status quo, although the transition to more collaborative management has been slow. The general shift in forest governance in Canada in recent years is from a singular focus on timber to a paradigm of sustainable forest management in which a broader range of values is considered in forest management decision making (CCFM 2003). Practices within these two Maritime provinces shed light on how Canada as a whole is pursuing sustainable forest management, but province-to-province variations exist in achieving this objective.

\section{CONCLUSION}

We examined several public participatory processes for public (Crown) land management over a 15-year period in NB and NS, with the goal of understanding more fully the perceived barriers and bridges to meaningful public participation and the relation between perceptions and implementation. Our results illustrate the importance of assessing public participation over time because outside factors such as a closed policy environment can erode even sound public participation processes. Over time, unsatisfying policy outcomes associated with absent or ineffective implementation have adversely affected the perceived value of participatory processes, degrading trust in the overall participatory environment. An absence of implementation following public participation processes supports the thesis of a participatory environment of agency capture in NB over the long term. An agency-client relation characteristic of agency capture is the inability to equitably manage on behalf of the broad public because of a close association with a particular interest group.
The NS government has historically followed a similar trend with a closed policy environment. Recently, its commitment to a more collaborative approach demonstrates a willingness for transformative change. This commitment remains to be fulfilled.

Specific, salient findings include: (1) the importance of historical and cultural context because ongoing power imbalances shape the current dialogue and spaces for participation; (2) periods of robust attempts at public participation in both provinces, but with disappointments in implementation that have led to feelings of meaningless involvement, a closed system, and mistrust in the government and industry; (3) a system of privileged access that runs counter to the ideals of deliberative democracy and an equitable decision-making process; (4) policy outcomes that are not reflective of participatory processes or of interests outside government and industry, which is illustrative of how capture functions in NB; (5) recent efforts in NS to incorporate values outside the government-industry policy realm in an attempt to shift toward a more collaborative system, but with a slow transition to substantive implementation.

Historical and cultural aspects play a role in power dynamics, with traditional parties maintaining privileged roles. Although there have been episodic spaces for public participation in Crown land management and decision making in NB, the last meaningful effort occurred in the late 2000s. Implementation of progressive policies in a captured environment is unlikely to occur, especially because environmental groups, woodlot owners, and regular citizens do not have access to government decision-making processes and do not have institutionalized opportunities to voice concerns about Crown land management. This conundrum is seen in the episodic spaces that open for participation, the momentum in a collaborative direction that ensues, and the expression of outside, diverse interests, which activities often end with an implementation of policy that follows the historical trend of support for large industrial interests. Without a strong commitment by government to a sound, institutionalized process and a rebalance of power, the incorporation of values outside the historical status quo is unlikely. Such a commitment by government has been made in NS. It is through policy implementation that the extent of the transformation in NS's public land policy will be measured in the future. We will then know if such a transformation leads to a widespread change of culture or becomes a missed opportunity on the road to the social objective of sustainable forest management.

${ }^{[1]}$ Recently, alternative media outlets have exposed correspondence between the major industrial player in NB and former Premier Alward. To access the documents, refer to http://halifax. mediacoop.ca/story/exclusive-when-billionaire-writes-you-listen/34417.

Responses to this article can be read online at: http://www.ecologyandsociety.org/issues/responses. $\mathrm{php} / 9142$

\section{Acknowledgments:}

We thank the Community-University Research Alliance for financial support for this research. 


\section{LITERATURE CITED}

Anderson, J., and S. Yaffee. 1998. Balancing public trust and private interest: public participation in habitat conservation planning: a summary report. School of Natural Resources, University of Michigan, Ann Arbor, Michigan, USA. [online] URL: http://seas. umich.edu/ecomgt//pubs/hcp.pdf

Anderson, W. F. A., and D. A. MacLean. 2015. Public forest policy development in New Brunswick, Canada: multiple streams approach, advocacy coalition framework, and the role of science. Ecology and Society 20(4):20. http://dx.doi.org/10.5751/ es-07795-200420

Auditor General of New Brunswick. 2015. Report of the Auditor General of New Brunswick 2015. Volume II. Legislative Assembly of New Brunswick, Fredericton, Canada. [online] URL: http:// www.agnb-vgnb.ca/content/dam/agnb-vgnb/pdf/ReportsRapports/2015V2/Agrepe.pdf

Bachmann, R. and A. Zaheer, editors. 2006. Handbook of trust research. Edward Elgar, Cheltenham, UK.

Baskerville, G. L. 1988. Redevelopment of a degrading forest system. Ambio 17(5):314-322. [online] URL: http://www.jstor. org/stable/4313487

Baskerville, G. L. 1995. The forestry problem: adaptive lurches of renewal. Pages 37-102 in L. H. Gunderson, C. S. Holling, and S. S. Light, editors. Barriers and bridges to the renewal of ecosystems and institutions. Columbia University Press, New York, New York, USA.

Beckley, T. M. 2014. Public engagement, planning, and politics in the forest sector in New Brunswick, 1997-2014. Journal of New Brunswick Studies 5:41-65. [online] URL: https://journals.lib.unb. ca/index.php/JNBS/article/view/22337/25939

Beckley, T. M., J. R. Parkins, and S. Sheppard. 2006. Public participation in sustainable forest management: a reference guide. Sustainable Forest Management Network, Edmonton, Canada. [online] URL: https://cfs.nrcan.gc.ca/publications?id=26206

Beierle, T. C., and J. Cayford. 2002. Democracy in practice: public participation in environmental decisions. Resources for the Future, Washington, D.C., USA.

Beierle, T. C., and D. M. Konisky. 2000. Values, conflict, and trust in participatory environmental planning. Journal of Policy Analysis and Management 19(4):587-602. http://dx.doi. org/10.1002/1520-6688(200023)19:4<587::aid-pam4>3.0.co;2-q

Biernacki, P., and D. Waldorf. 1981. Snowball sampling: problems and techniques of chain referral sampling. Sociological Methods and Research 10(2):141-163. https://doi.org/10.1177/004912418101000205

Brownill, S., and J. Carpenter. 2007. Increasing participation in planning: emergent experiences of the reformed planning system in England. Planning Practice and Research 22(4):619-634. http:// dx.doi.org/10.1080/02697450701770134

Burrill, G., and I. McKay, editors. 1987. People, resources, and power: critical perspectives on underdevelopment and primary industries in the Atlantic region. Acadiensis Press, Fredericton, Canada.

CBC News. 2014. New forestry plan provides more Crown wood to industry: strategy expected to encourage investment, create new jobs, government says. $C B C$ News 12 March 2014. [online] URL: http://www.cbc.ca/news/canada/new-brunswick/new-forestry-planprovides-more-crown-wood-to-industry-1.2568734

Canadian Council of Forest Ministers (CCFM). 2003. Defining sustainable forest management in Canada: criteria and indicators. Canadian Forest Service, Ottawa, Canada. [online] URL: http:// cfs.nrcan.gc.ca/pubwarehouse/pdfs/23636.pdf

Canadian Council of Forest Ministers (CCFM). 2006. Criteria and indicators of sustainable forest management in Canada: national status 2005. Canadian Forest Service, Ottawa, Canada. [online] URL: http://www.ccfm.org/pdf/C\&I_e.pdf

Canadian Council of Forest Ministers (CCFM). 2016. Provice of New Brunswick. Forestry fact sheet. Canadian Forest Service, Ottawa, Canada. [online] URL: http://www.sfmcanada.org/ images/Publications/EN/New Brunswick info Provinces and territories EN.pdf

Carr, D. S., S. W. Selin, and M. A. Schuett. 1998. Managing public forests: understanding the role of collaborative planning. Environmental Management 22(5):767-776. http://dx.doi.org/10.1007/ $\underline{\mathrm{s} 002679900146}$

Charmaz, K. 2006. Constructing grounded theory: a practical guide through qualitative analysis. Sage, Thousand Oaks, California, USA.

Chess, C., and K. Purcell. 1999. Public participation and the environment: Do we know what works? Environmental Science and Technology 33(16):2685-2692. http://dx.doi.org/10.1021/ es980500g

Colin Stewart Forest Forum Steering Committee. 2009. Colin Stewart Forest Forum final report. In relation to Environmental Goals and Sustainable Prosperity Act. Nova Scotia Environment and the Nova Scotia Department of Natural Resources, Halifax, Canada. [online] URL: http://novascotia.ca/nse/protectedareas/ docs/CSFF finalreport sign.pdf

Cook, B. R., M. Kesby, I. Fazey, and C. Spray. 2013. The persistence of 'normal' catchment management despite the participatory turn: exploring the power effects of competing frames of reference. Social Studies of Science 43(5):754-779. http://dx.doi.org/10.1177/0306312713478670

Cortner, H. J., and M. A. Moote. 1999. The politics of ecosystem management. Island Press, Washington, D.C., USA.

Culhane, P. J. 1981. Public lands politics: interest group influence on the Forest Service and the Bureau of Land Management. Resources for the Future, New York, New York, USA.

Diduck, A., and A. J. Sinclair. 2002. Public involvement in environmental assessment: the case of the nonparticipant. Environmental Management 29(4):578-588. http://dx.doi.org/10.1007/ $\underline{\mathrm{s} 00267-001-0028-9}$

Fiorino, D. J. 2006. The new environmental regulation. MIT Press, Cambridge, Massachusetts, USA.

Floyd, D. W., R. Ritchie, and T. Rotherham. 2012. New approach for private woodlots: reframing the forest policy debate. Private Forest Task Force Report. Province of New Brunswick, Fredericton, Canada. [online] URL: http://www2.gnb.ca/ 
content/dam/gnb/Departments/nr-rn/pdf/en/ForestsCrownLands/ NewApproachesForPrivateWoodlots.pdf

Fortmann, L. 1990. The role of professional norms and beliefs in the agency-client relations of natural resource bureaucracies. Natural Resources Journal 30(2):361-380. [online] URL: http:// www.jstor.org/stable/24883577

Fullerton, G. 2012. Good advice: What makes an effective forest advisory committee? Atlantic Forestry Review 18(5):42-43.

Gaventa, J. 1980. Power and powerlessness: quiescence and rebellion in an Appalachian valley. University of Illinois Press, Urbana, Illinois, USA.

Gaventa, J. 2006. Finding the spaces for change: a power analysis. IDS Bulletin 37(6):23-33. http://dx.doi.org/10.1111/j.1759-5436.2006. tb00320.x

Germain, R. H., D. W. Floyd, and S. V. Stehman. 2001. Public perceptions of the USDA Forest Service public participation process. Forest Policy and Economics 3(3-4):113-124. http://dx. doi.org/10.1016/s1389-9341(01)00065-X

Giddings, L. S. 2006. Mixed-methods research: positivism dressed in drag? Journal of Research in Nursing 11(3):195-203. https://doi. org/10.1177/1744987106064635

Hesse-Biber, S. N., and P. Leavy. 2011. The practice of qualitative research. Second edition. Sage, Thousand Oaks, California, USA.

Holloway, N., G. A. Jordan, and B. M. Smith. 2008. Management of New Brunswick's Crown forest during the twentieth century. Forestry Chronicle 84(4):481-491. http://dx.doi.org/10.5558/ tfc84481-4

Höppner, C. 2009. Trust-a monolithic panacea in land use planning? Land Use Policy 26(4):1046-1054. http://dx.doi. org/10.1016/j.landusepol.2008.12.007

Hourdequin, M., P. Landres, M. J. Hanson, and D. R. Craig. 2012. Ethical implications of democratic theory for U.S. public participation in environmental impact assessment. Environmental Impact Assessment Review 35:37-44. http://doi.org/10.1016/j. eiar.2012.02.001

Ishak, N. M., and A. Y. A. Bakar. 2014. Developing sampling frame for case study: challenges and conditions. World Journal of Education 4(3):29-35. https://doi.org/10.5430/wje.v4n3p29

LaPierre, L., S. Woodley, and G. Forbes. 1998. A protected areas strategy for New Brunswick: an ecoregion-based approach. New Brunswick Department of Natural Resources, Fredericton, Canada.

Leach, W. D. 2006. Collaborative public management and democracy: evidence from western watershed partnerships. Public Administration Review 66(S1):100-110. http://dx.doi.org/10.1111/ j.1540-6210.2006.00670.x

Lefebvre, H. 1991. The production of space. (Translated by D. Nicholson-Smith). Blackwell, Oxford, UK.

Léger, M., J. McLaughlin, and C. M. G. Robertson. 2016. New Brunswick Commission on Hydraulic Fracturing - volume I: the findings. NB Commission on Hydraulic Fracturing, Fredericton,
Canada. [online] URL: http://www2.gnb.ca/content/dam/gnb/ Departments/en/pdf/Publications/NBCHF-Vol1-Eng-Feb2016.pdf

Lindsey, D. 2014. Northern Pulp, western Crown: the politics of wood supply and public consultation. Atlantic Forestry Review 20(4):20-21.

Maritime Regions Steering Committee. 2008. Certification standards for best forestry practices in the Maritimes region. Forest Stewardship Council Canada, Toronto, Canada. [online] URL: https://ca.fsc.org/preview.maritimes-standard.a-826.pdf

Martin, G. 2003. Management of New Brunswick's Crown forest. New Brunswick Department of Natural Resources, Fredericton, Canada. [online] URL: http://leg-horizon.gnb.ca/e-repository/ monographs/30000000044011/30000000044011.pdf

Miller, A. 1993. The role of citizen scientist in nature resource decision-making: lessons from the spruce budworm problem in Canada. Environmentalist 13(1):47-59. http://dx.doi.org/10.1007/ bf01905503

Miller, A., and P. Rusnock. 1993. The rise and fall of the silvicultural hypothesis in spruce budworm (Choristoneura fumiferana) management in eastern Canada. Forest Ecology and Management 61(1-2):171-189. http://dx.doi.org/10.1016/0378-1127 (93)90197-u

Nadeau, S., T. M. Beckley, E. Huddart Kennedy, B. L. McFarlane, and S. Wyatt. 2007. Public views on forest management in New Brunswick: report from a provincial survey. Information report MX-222E. Canadian Forest Service Atlantic Forestry Centre, Fredericton, Canada. [online] URL: https://cfs.nrcan.gc.ca/ publications? $\mathrm{id}=28113$

Neuman, W. L. 2009. Social research methods: qualitative and quantitative approaches. Seventh edition. Pearson/Allyn and Bacon, Boston, Massachusetts, USA.

New Brunswick Department of Natural Resources (NBDNR). 2004. Staff review of the Jaakko Pöyroy report: New Brunswick Crown forests: assessment of stewardship and management. New Brunswick Department of Natural Resources, Fredericton, Canada. [online] URL: http://www2.gnb.ca/content/dam/gnb/ Departments/nr-rn/pdf/en/Publications/Jaakko Poyry FINAL.pdf

New Brunswick Department of Natural Resources (NBDNR). 2005a. Objectives and standards for the New Brunswick Crown forest for the 2007-2012 period. New Brunswick Department of Natural Resources, Fredericton, Canada. [online] URL: http:// www2.gnb.ca/content/dam/gnb/Departments/nr-rn/pdf/en/

ForestsCrownLands/TechnicalVision.pdf

New Brunswick Department of Natural Resources (NBDNR). 2005b. The New Brunswick public forest: our shared future. New Brunswick Department of Natural Resources, Fredericton, Canada. [online] URL: http://leg-horizon.gnb.ca/e-repository/ monographs/30000000043979/30000000043979.pdf

New Brunswick Department of Natural Resources (NBDNR). 2014. A strategy for Crown lands forest management: putting our resources to work. New Brunswick Department of Natural Resources, Fredericton, Canada. [online]URL: http://www2.gnb. ca/content/dam/gnb/Departments/nr-rn/pdf/en/ForestsCrownLands/ AStrategyForCrownLandsForestManagement.pdf 
Nova Scotia Department of Natural Resources (NSDNR). 2011. The Path We Share: a natural resources strategy for Nova Scotia 2011-2020. Nova Scotia Department of Natural Resources, Halifax, Canada. [online] URL: http://novascotia.ca/natr/ strategy/pdf/ThePathWeShareReportOnline5Year.pdf

Nova Scotia Department of Natural Resources (NSDNR). 2013a. Public consultation and engagement process: Crown lands use western region: summary report. Nova Scotia Department of Natural Resources, Halifax, Canada. [online] URL: http://0nsleg-edeposit.gov.ns.ca.legcat.gov.ns.ca/deposit/b10659390.pdf

Nova Scotia Department of Natural Resources (NSDNR). 2013b. The Path We Share: a natural resources strategy for Nova Scotia 2011-2020: 24-month progress report. Nova Scotia Department of Natural Resources, Halifax, Canada. [online] URL: http://0-nsleg-edeposit.gov.ns.ca.legcat.gov.ns.ca/deposit/ b10664233.pdf

Nova Scotia Department of Natural Resources (NSDNR). 2015. Crown land management: a conceptual plan for western Nova Scotia: updated August 2015. Nova Scotia Deparmtnet of Natural Resources, Halifax, Canada. [online] URL: https://novascotia.ca/ natr/land/western-land/pdf/western-crown-lands-update-August2015. pdf

Nova Scotia Department of Natural Resources (NSDNR). 2016. The Path We Share: a natural resource strategy for Nova Scotia 2011-2020: five-year progress report. Nova Scotia Deparmtnet of Natural Resources, Halifax, Canada. [online] URL: http:// novascotia.ca/natr/strategy/pdf/ThePathWeShareReportOnline5Year. pdf

Ostrom, E. 1990. Governing the commons: the evolution of institutions for collective action. Cambridge University Press, Cambridge, Massachusetts, USA.

Ostrom, E. 2008. The challenge of common-pool resources. Environment: Science and Policy for Sustainable Development 50 (4):8-21. http://dx.doi.org/10.3200/envt.50.4.8-21

Ostrom, E. 2009. Beyond markets and states: polycentric governance of complex economic systems. Nobel Prize lecture. Nobel Media, Stockholm, Sweden. [online] URL: http://www. nobelprize.org/nobel prizes/economic-sciences/laureates/2009/ ostrom lecture.pdf

Ozinga, S., and L. Krul. 2004. Footprints in the forest: current practices and future challenges in forest certification. Fern, Moreton in Marsh, UK. [online] URL: http://www.fern.org/sites/ fern.org/files/media/documents/document 1890 1900.pdf

Parenteau, B. 2013. Looking backward, looking ahead: history and future of the New Brunswick forest industries. Acadiensis 42 (2):92-113. [online] URL: https://journals.lib.unb.ca/index.php/ Acadiensis/article/view/21105/24362

Parkins, J. R., and D. J. Davidson. 2008. Constructing the public sphere in compromised settings: environmental governance in the Alberta forest sector. Canadian Review of Sociology 45 (2):177-196. http://dx.doi.org/10.1111/j.1755-618x.2008.00009.x

Parkins, J. R., and R. E. Mitchell. 2005. Public participation as public debate: a deliberative turn in natural resource management. Society and Natural Resources 18(6):529-540. http://dx.doi.org/10.1080/08941920590947977
Parkins, J. R., S. Nadeau, L. M. Hunt, J. Sinclair, M. G. Reed, and S. Wallace. 2006. Public participation in forest management: results from a national survey of advisory committees. Information Report NOR-X-409E. Canadian Forest Service Northern Forestry Centre, Edmonton, Canada. [online] URL: https://cfs. nrcan.gc.ca/publications? $\mathrm{id}=26570$

Reed, M. S. 2008. Stakeholder participation for environmental management: a literature review. Biological Conservation 141 (10):2417-2431. http://dx.doi.org/10.1016/j.biocon.2008.07.014

Ribot, J. C. 2003. Democratic decentralisation of natural resources: institutional choice and discretionary power transfers in Sub-Saharan Africa. Public Administration and Development 23(1):53-65. http://dx.doi.org/10.1002/pad.259

Rowe, G., and L. J. Frewer. 2004. Evaluating public-participation exercises: a research agenda. Science, Technology and Human Values 29(4):512-556. http://dx.doi.org/10.1177/0162243903259197

Sandberg, L. A. 1992. Introduction: dependent development and client states forest policy and social conflict in Nova Scotia and New Brunswick. Pages 1-21 in L. A. Sandberg, editor. Trouble in the woods: forest policy and social conflict in Nova Scotia and New Brunswick. Acadiensis Press, Fredericton, Canada.

Sandberg, L. A., and P. Clancy. 1996. Property rights, small woodlot owners and forest management in Nova Scotia. Journal of Canadian Studies/Revue d'études Canadiennes 31(1):25-47. http://dx.doi.org/10.3138/jcs.31.1.25

Sandberg, L. A., and P. Clancy. 2002. Politics, science and the spruce budworm in New Brunswick and Nova Scotia. Journal of Canadian Studies/Revue d'études Canadiennes 37(2):164-191. http://dx.doi.org/10.3138/jcs.37.2.164

Schlager, E. 2004. Common-pool resource theory. Pages 145-175 in R. F. Durant, D. J. Fiorino, and R. O'Leary, editors. Environmental governance reconsidered: challenges, choice, and opportunities. MIT Press, Cambridge, Massachusetts, USA.

Scrine, J. 2014. N.S. community forest gets green light: co-op settles for smaller and land base, eyes wood year, bio-energy revenue. Atlantic Forestry Review 20(3):24-26.

Select Committee on Wood Supply. 2004. Final report on wood supply in New Brunswick. Legistlative Assembly of New Brunswick, Fredericton, Canada. [online] URL: http://www.gnb. ca/legis/business/committees/reports/Wood/legwoodfinal-e.pdf

Selznick, P. 1949. TVA and the grass roots: a study in the sociology of formal organization. University of California Press, Berekley, California, USA.

Simmons, W. M. 2007. Participation and power: civic discourse in environmental policy decisions. State University of New York Press, Albany, New York, USA.

Singleton, S. 2000. Co-operation or capture? The paradox of comanagement and community participation in natural resource management and environmental policy-making. Environmental Politics 9(2):1-21. http://dx.doi.org/10.1080/09644010008414522

Slocum, R., L. Wichhart, D. Rocheleau, and B. Thomas-Slayter. 1995. Power, process and participation: tools for change. Intermediate Technology Publications, Bradford, UK. 
Stringer, L. C., A. J. Dougill, E. Fraser, K. Hubacek, C. Prell, and M. S. Reed. 2006. Unpacking "participation" in the adaptive management of social-ecological systems: a critical review. Ecology and Society 11(2):39. [online] URL: http://www. ecologyandsociety.org/vol11/iss2/art39/

Task Force on Forest Diversity and Wood Supply. 2008. Management alternatives for New Brunswick's public forest. Report of the New Brunswick Task Force on Forest Diversity and Wood Supply (Erdle Report). New Brunswick Department of Natural Resources, Fredericton, Canada. [online] URL: http:// www2.gnb.ca/content/dam/gnb/Departments/nr-rn/pdf/en/ ForestsCrownLands/Erdle/ErdleReport-e.pdf

Tuler, S., and T. Webler. 1999. Voices from the forest: what participants expect of a public participation process. Society and Natural Resources 12(5):437-453. http://dx.doi.org/10.1080/089$\underline{419299279524}$

United Nations. 2015. United Nations forum on forest: report on the eleventh session (19 April 2013 and 4 to 15 May 2015). Economic and Social Council, United Nations, New York, New York, USA. [online] URL: http://dx.doi.org/10.18356/fe43e5e4en

Wallace, L. J. 2012. An actor-network approach to Canadian forest research: the case of a New Brunswick policy debate. Canadian Geographer 56(3):362-380. http://dx.doi.org/10.1111/ j.1541-0064.2012.00436.x

Weimer, D. L., and A. R. Vining. 1999. Policy analysis: concepts and practice. Prentice Hall, Upper Saddle River, New Jersey, USA.

Wyatt, S. 2014. Checks and balances in New Brunswick's forest management regime. NB Naturalist 41(1):25-27. [online] URL: http://www.naturenb.ca/wp-content/uploads/2013/01/NB-NaturalistVol.41-No.1-Colour-August-29.pdf

Wyatt, S., M. Kessels, and F. van Laerhoven. 2015. Indigenous peoples' expectations for forestry in New Brunswick: Are rights enough? Society and Natural Resources 28(6):625-640. http://dx. doi.org/10.1080/08941920.2014.970735

Young, I. M. 1990. Justice and the politics of difference. Princeton University Press, Princeton, New Jersey, USA. 